\title{
EMISSION OF SELECTED EXHAUST GAS COMPONENTS AND FUEL CONSUMPTION IN DIFFERENT DRIVING CYCLES
}

\author{
Andrzej Kuranc $^{1, *}$, Jacek Caban², Branislav Šarkan ${ }^{3}$, Agnieszka Dudziak$^{1}$, Monika Stoma ${ }^{1}$ \\ ${ }^{1}$ Department of Power Engineering and Transportation, Faculty of Production Engineering, University of Life \\ Sciences in Lublin, Lublin, Poland \\ ${ }^{2}$ Department of Automation, Faculty of Mechanical Engineering, Lublin University of Technology, Lublin, Poland \\ ${ }^{3}$ Department of Road and Urban Transport, Faculty of Operation and Economics of Transport and Communications, \\ University of Zilina, Zilina, Slovak Republic
}

*E-mail of corresponding author: andrzej.kuranc@up.lublin.pl

\section{Resume}

Road transport have significant impact on regional economic and social development, but one can also point out a number of its disadvantages, which include environmental pollution. The paper presents measurements of fumes exhaust emissions of a passenger car with a significant operational mileage. The tests were carried out in a laboratory on a chassis roller dynamometer using various driving cycles. To determine the exhaust emissions, data on the mass of air flowing through the intake manifold was used, among others. The work also describes an example of own driving cycle developed based on urban driving in Lublin, Poland.

Available online: https://doi.org/10.26552/com.C.2021.4.B265-B277

\section{Article info}

Received 17 September 2020

Accepted 15 January 2021

Online 20 August 2021

\section{Keywords:}

exhaust emission, internal combustion engine, standardisation, vehicle operation

\section{Introduction}

In addition to many positive aspects of the development in the automotive industry, one can also point out to a number of its disadvantages, which include environmental pollution. Scientists and legislators are working together to eliminate, or at least reduce, the environmental impact of vehicles. To reduce the problem of pollution from transport, the $\mathrm{EU}$ is introducing increasingly stringent emission standards, which should correspond to sustainable conditions of the environment during the operation of motor vehicles [1]. They are mainly concerned with the reduction of emissions of such components as: carbon monoxide, hydrocarbons, nitrogen oxides and solid particles. In Europe, Euro standards are used, which have been developed in a series of European Directives [2]. The first standard was the Euro 1 standard issued in 1993, while the latest one is Euro 6, which was introduced in 2014. The next stages of the Euro 6 standards - Euro 6B, 6C, 6D-TEMP and $6 \mathrm{D}$ - are increasingly raising the requirements for new engines [3]. Modern cars must emit significantly less harmful substances than vehicles from the 90 s. To do that, manufacturers use, among others, AdBlue preparation, oxidation catalysts or particulate filters [4-5]. However, it turns out that the fight against one problem raises another. Recently, petrol engines are also equipped with GPF particulate filters. Unfortunately, by reducing the fuel consumption and $\mathrm{CO}_{2}$ emissions, solutions have been introduced that have increased the amount of particulate matter emitted by petrol engines. Nowadays, there are more types of propulsions and fuels in road transport [6].

The average $\mathrm{CO}_{2}$ emission of new cars sold in the European Union in 2018 was at the level of $120.5 \mathrm{~g} / \mathrm{km}$. From the beginning of 2020 , $95 \%$ of cars sold in the European Union must meet the average maximum $\mathrm{CO}_{2}$ emission limit of $95 \mathrm{~g} / \mathrm{km}$ [7-8]. To reduce the fuel consumption and, consequently $\mathrm{CO}_{2}$ emissions, manufacturers use the so-called downsizing or electric motors next to internal combustion ones. Downsizing is associated with use of a smaller-sized internal combustion engine, however, with similar performance parameters. That is possible mainly thanks to turbochargers or compressors [9-10]. In order to reduce emissions and effort to consume fewer non-renewable resources and use primarily raw materials of biological origin, the solution that has been used for many years is the use of alternative fuels [11-13], i.e. the use of an internal combustion engine as a dual-fuel engine [14-16]. Another solution is hybrid propulsion systems, consisting of a combustion unit and usually a supporting 
electrical unit. The introduction of an electric unit allows for a temporary increase in the power of the vehicle's propulsion system while reducing fuel consumption (as well as carbon dioxide emissions).

The electric motor can support the internal combustion engine, or it can be the main one and the internal combustion engine works as a generator then. The 1997 Toyota Prius was the first car being produced on a large scale hybrid car. Other commonly available hybrid vehicles are: Honda CR-Z, Toyota Yaris, Chevrolet Volt and Opel Ampera. It is observed that the sale of electric cars is growing dynamically and the number of electric vehicles sold is doubling from year to year [1718]. Despite the undoubted advantages concerning zero exhaust emissions at the place of use of a vehicle, or its movement dynamics, electric cars still have competition in terms of the carbon footprint. Vehicles with selfignition engines powered by diesel fuel are again proving to be the cheapest in relation to electric vehicles, which are being charged from stations available in cities and on motorways [19]. Vehicle manufacturers, such as Mazda, are also joining the discussion, pointing out that the long distance driving can be associated with higher $\mathrm{CO}_{2}$ emissions than using a diesel vehicle [20].

The Polish market is growing slower than in European neighboring countries [21]. There are still many proponents of combustion engine powered vehicles and it can be assumed that the electric engines will not so easily press the combustion ones out of the market. On the other hand, the increase in popularity of electric vehicles will reduce the demand for liquid fuels. This will affect their lower sales and lower revenues to the state budgets due to excise duty and that will certainly result in an increase in electricity charges.

Therefore, remaining with vehicles powered by internal combustion engines, it should be noted that many vehicles with a significant mileage, which is measured in hundreds of thousands of kilometers, are driven in Poland. The average age of a car on Polish roads in 2018 was about 14 years - according to data from the European Automobile Manufacturers Association (ACEA). The average vehicle age for European countries is 11 years. The oldest cars in the European Union run on the roads of Romania - the average age of passenger cars reaches 16 years [22]. For many vehicles with such a degree of operation, this is the time when the deficiencies of functioning fuel apparatus and exhaust after-treatment system occur [23-25].

\section{Research objective}

The purpose of the work was to determine the combustion ones exhaust emissions from a vehicle with a high mileage in relation to selected driving cycles, as well as based on the authors' own urban driving cycle, being a sample of traffic conditions in Lublin, Poland. The impact of the cycles on exhaust emissions and fuel consumption was assessed. The exhaust emissions tests were to assess the vehicle's technical condition in relation to emission standards for the given model.

\section{Research methodology}

Exhaust emission tests were carried out in the laboratory of the Department of Power Engineering and Transport Means of the University of Life Sciences in Lublin. A car equipped with a turbocharged diesel engine was tested. The vehicle participated in 4 driving cycles (3 were official cycles commonly used in vehicle testing and one was a cycle developed by the authors of the work, mapping the road conditions on a selected route in the center of Lublin). The cycles were carried out on MAHA MSR 500 single roller chassis dynamometer. The exhaust emissions tests were carried out using a simplified measurement procedure based on e use of the diagnostic tools MAHA MGT 5 gas analyzer and MAHA MPM 4 particulate emission meter. In addition, the VIAKEN diagnostic engine parameter reader/recorder and a smartphone with a GPS receiver equipped with an application for registering the distance travelled were used for the preparation of the tests.

\subsection{Tested object}

The object of the study was Volkswagen Golf A4 (Type 1J) manufactured in 2002 with a mileage of $312000 \mathrm{~km}$ (Figure 1). The vehicle was fitted with a $1.9 \mathrm{dm}^{3}$ direct-injection turbodiesel ASV engine of maximum torque $235 \mathrm{Nm}$ at $1900 \mathrm{~min}^{-1}$ and maximum power output of $81 \mathrm{~kW}$ at $4150 \mathrm{~min}^{-1}$, equipped with an exhaust gas recirculation system, variable turbine geometry (VTG) and oxidation reactor. The vehicle was adapted to comply with Euro 3 standard (Table 1). It also had a DLC connector enabling communication with OBD system and recording several data, such as engine's RPM and MAF (manifold air flow).

The technical condition of the vehicle and the engine in particular, was assumed as fair. At mileage of about $256000 \mathrm{~km}$, the turbocharger was damaged. It became unsealed and the engine oil leaked into the exhaust system. Then the turbocharger was reconditioned and reinstalled. Taking into account the above mentioned situation it could be assumed that the technical condition of the catalyst was strained. The OBD system did not indicate any malfunctions and the owner of the vehicle declared that throughout the period of operation, maintenance activities had been performed on an ongoing basis and the replacement of engine oil, filters and timing components had been carried out in accordance with the recommended service schedule. At about $290000 \mathrm{~km}$ the exhaust braid became unsealed and then replaced. Before the driving cycle tests, dosing of the fuel injectors was checked and no deviations 


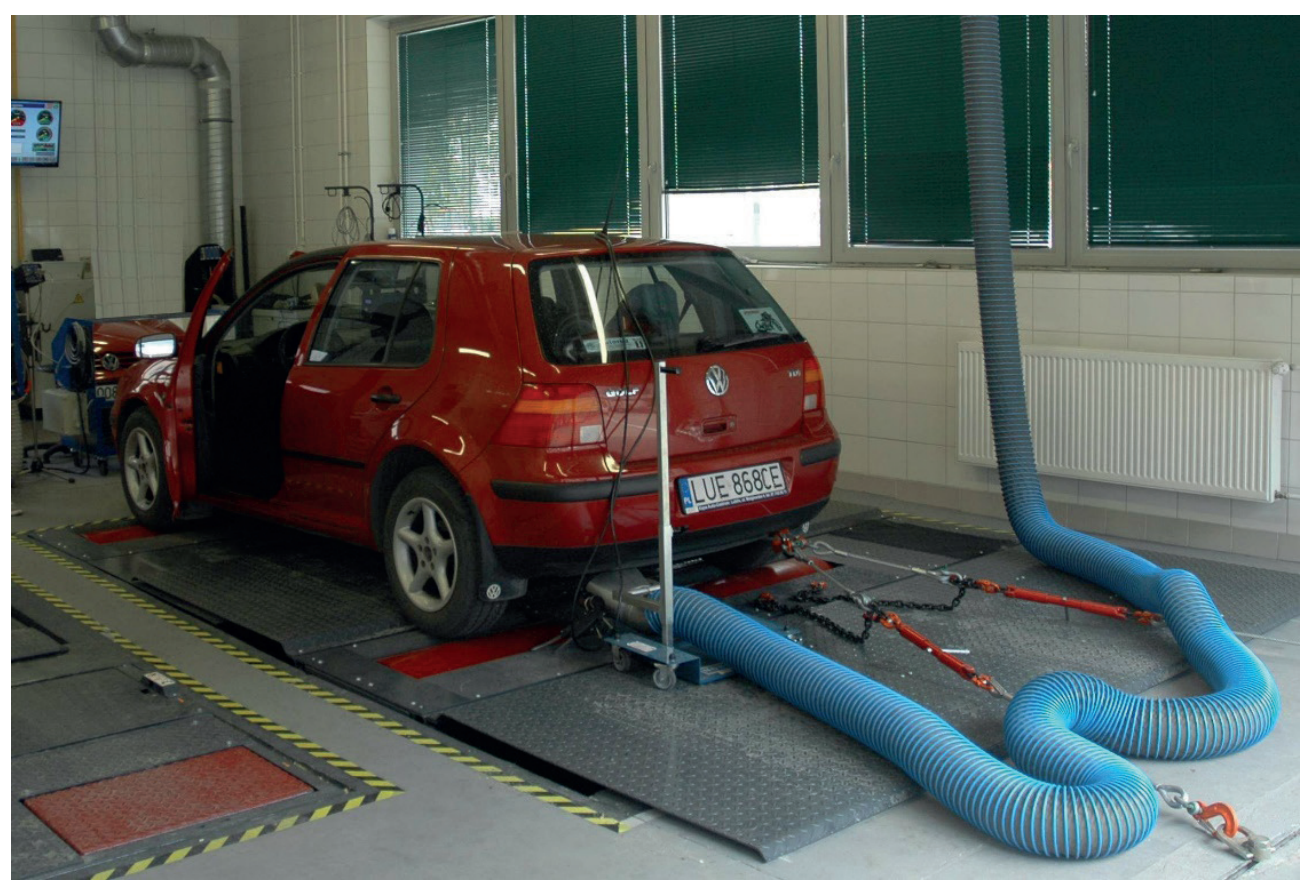

Figure 1 Tested vehicle at the test stand, source: authors

Table 1 Type approval emission limits for the tested vehicle, [2]

\begin{tabular}{|c|c|c|c|c|c|c|}
\hline curb mass & engine type & \multicolumn{4}{|c|}{ emission limit values, $\mathrm{g} \times \mathrm{km}^{-1}$} & valid from \\
\hline \multirow[t]{2}{*}{ less than $2620 \mathrm{~kg}$} & compression & $\mathrm{CO}$ & $\mathrm{HC}$ & NOx & PM & \multirow{2}{*}{01.01 .2000} \\
\hline & ignition & 0.64 & 0.06 & 0.50 & 0.05 & \\
\hline
\end{tabular}

Table 2 Chosen technical data of the research object

\begin{tabular}{ccc}
\hline no. & fuel consumption & directive $80 / 1268-1999 / 100 \mathrm{UE}$ \\
\hline 1. & urban & $6.5 \mathrm{dm}^{3} / 100 \mathrm{~km}$ \\
2. & suburban & $4.0 \mathrm{dm}^{3} / 100 \mathrm{~km}$ \\
3. & average - combined & $4.9 \mathrm{dm}^{3} / 100 \mathrm{~km}$ \\
4. & $\mathrm{CO}^{2}$ emission & $132 \mathrm{~g} / \mathrm{km}$ \\
5. & emission standard & euro 3 \\
6. & fuel & diesel fuel \\
7. & curb mass & $1275 \mathrm{~kg}$ \\
8. & test mass & $1360 \mathrm{~kg}$ \\
9. & engine model & $\mathrm{ASV}$ \\
10. & displacement & $1896 \mathrm{~cm}{ }^{3}$ \\
11. & cylinders & 4 in line \\
12. & fuel injection & direct \\
13. & valves & $8 \mathrm{v}, \mathrm{SOHC}$ \\
14. & maximum power & $81 \mathrm{~kW}$ at $4150 \mathrm{rpm}$ \\
15. & maximum torque & $235 \mathrm{Nm}$ at $1900 \mathrm{rpm}$ \\
16. & gearbox & 5 gears, manual \\
17. & drive & front wheel drive \\
18. & top speed & $192 \mathrm{~km} / \mathrm{h}$ \\
19. & acceleration time $0-100 \mathrm{~km} / \mathrm{h}$ & $11.3 \mathrm{~s}$ \\
\hline
\end{tabular}

beyond the tolerance range were found and the load tests on a chassis dynamometer showed performance results close to the values declared by the vehicle manufacturer.
Table 1 presents the type approval emission limits complied by the vehicle and the main important technical data of a vehicle are given in Table 2. 


\subsection{Equipment and its preparation}

\subsubsection{Emission measurements}

For the purpose of exhaust gas study, the 5-component diagnostic gas analyser was used. Typically, such an analyser allows measurements of volumetric shares of four gaseous components such as: carbon monoxide $\mathrm{CO}$, carbon dioxide $\mathrm{CO}_{2}$, hydrocarbons $\mathrm{HC}$ and oxygen $\mathrm{O}_{2}$. The used MAHA MGT5 is a "0" class by OIML (Organization Internationale de Metrologie Legale) analyser and it was additionally equipped with an electrochemical NOx concentration sensor. It was prepared to measure the rotational speed and engine oil temperature and also enabled communication with the vehicle's E-OBD module [26].

The MPM4 particulate emission meter is a device for measuring the mass concentration of particulates in a unit of exhaust gas volume. The measuring range extends from 0 to $700 \mathrm{mg} / \mathrm{m}^{3}$ and the laser measuring system used in it allows detecting particles sizing from $0.1 \mu \mathrm{m}$ to $10 \mu \mathrm{m}$ [27]. The MPM4 was aligned with the exhaust gas analyser MGT5 and a PC.

The manufacturer of the chassis dynamometer, the analyser and particle meter also provided a possibility of their cooperation. The aforementioned instruments, including a PC and dedicated MAHA software, made up the exhaust gas composition measuring-and-recording system [28-29].

In order to determine the mass emission, information on the mass of exhaust gases or the mass of air supplying the engine was needed. For this purpose, the VIAKEN $\mathrm{K}+\mathrm{L}$ diagnostic interface dedicated for VAG was used. The device allowed diagnostics of selected vehicle systems and registering chosen parameters of the vehicle's engine in driving conditions (e.g. rpm, MAF MAP, injection dose, injection timing, etc.) [30-31].

\subsubsection{Emission and fuel consumption calculations}

As it was mentioned, the exhaust gas analyzer performs measurements of the volumetric shares of given fumes components. The shares, combined with information about the exhaust gas flow, can give information about the amount of a component emitted. Based on the combustion equation, described in [30], the coefficients for combustion products and their volumetric shares for each set of data recorded second by second were determined. Thanks to that, the volumetric shares of fumes components, other than measured, were determined and then transformed into the mass shares. On the other hand, the mass of fumes is the sum of the mass of the air and the fuel delivered to the combustion chamber and it can be determined by the intake manifold air flow (MAF) and the fuel injected dose. However, due to the equipment and methods used in the research, some assumptions and simplifications were required [28].
The fuel consumption can be found in two ways. The mass of the supplied fuel is $1 /\left(\lambda^{*} \mathrm{AFR}\right)$ of the air mass. The composition of the exhaust gases can be used to determine the excess air ratio $(\lambda)$ needed to calculate the fuel consumption. For the diesel fuel $\left(\mathrm{C}_{1} \mathrm{H}_{1.86} \mathrm{O}_{0.005}\right)$ and the combustion reaction for the stoichiometric mixture $(\lambda=1)$ the calculated air-fuel ratio (AFR) equals 14.46. In a compression-ignition engine, combustion is not stoichiometric $(\lambda>1)$, but it is comprehensive and total. Since, the diesel engine operates with a higher excess of air, the right value of $\lambda$ can become known based on the fumes composition and Brettschneider's formula [32]. In this case the fuel consumption can be calculated as:

$$
F C=\frac{M A F}{\lambda \cdot A F R}
$$

where:

$F C$ - fuel consumption $(\mathrm{g} / \mathrm{s})$,

$M A F$ - measured manifold air flow $(\mathrm{g} / \mathrm{s})$,

$\lambda$ - air excess coefficient calculated by Brettschneider's formula (-),

$A F R$ - air/fuel ratio for stoichiometric mixture (kg/kg).

Another way to evaluate the fuel consumption is based on the OBD data. Use of the OBD data, concerning the fuel injection dose and the engine's rotational speed (RPM), allows to estimate the amount of fuel being consumed. In the case of four cylinder four stroke engine, the calculation formula has the form:

$$
F C=\frac{4 \cdot I Q \cdot R P M}{2 \cdot 60},
$$

where:

$F C$ - fuel consumption $(\mathrm{g} / \mathrm{s})$,

$I Q$ - fuel injection dose (g/cycle/injector),

$R P M$ - engine's rotational speed $\left(\mathrm{min}^{-1}\right)$.

Equations (1) and (2) lead to results expressed in grams per cycle. To compare the results, they should be divided by the length of a given cycle in $\mathrm{km}$. Dividing by the density of the diesel fuel $\left(0.84 \mathrm{~kg} / \mathrm{dm}^{3}\right)$ and multiplying by 100 leads to obtaining fuel consumption in $\mathrm{dm}^{3}$ per $100 \mathrm{~km}$.

\subsubsection{Chassis dynamometer}

Vehicle tests were carried out with MAHA's chassis dynamometer type MSR 500 (Figure 1). It was dedicated for vehicles with a wheel maximum power up to $250 \mathrm{~kW}$. This was a single-roller stand with a drum diameter of $500 \mathrm{~mm}$. The device could perform a continuous measurement of the driving force and rotational speed of the rollers driven by the vehicle wheels. At the same time, electronically controlled eddy-current brakes introduced additional load to the rollers to represent movement resistances, which are present in the road conditions [33].

Before starting the driving cycles, the load, that was to be applied by the test stand, had to be adjusted 


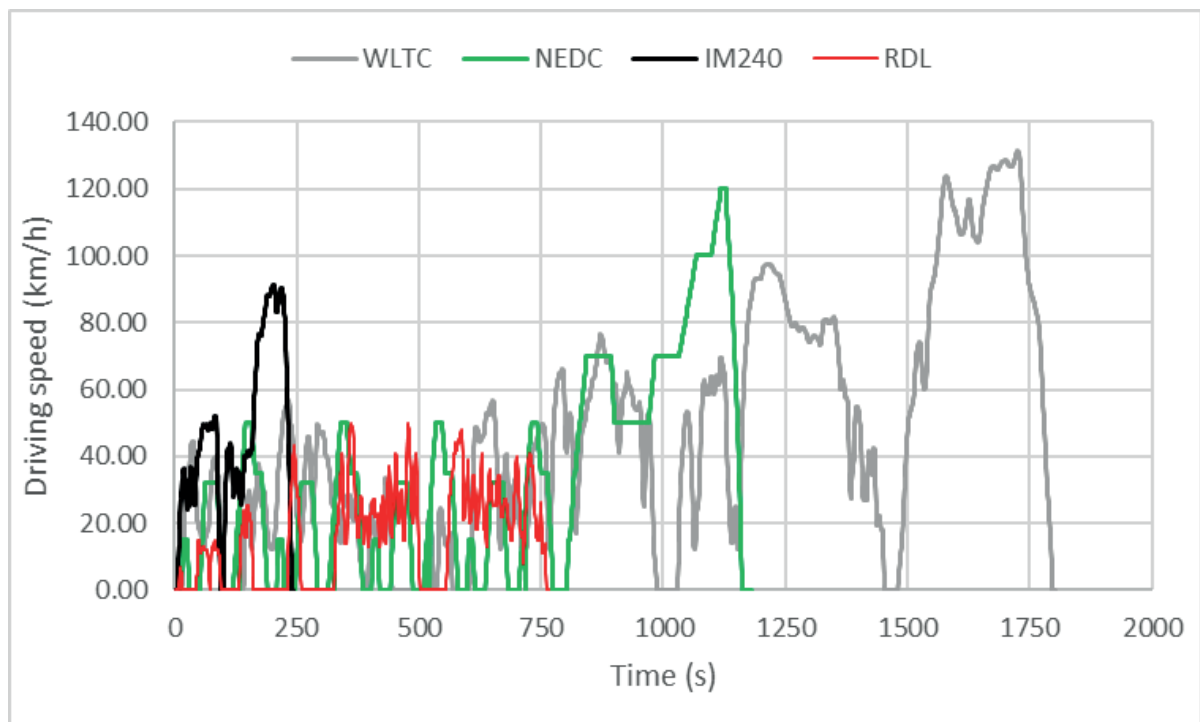

Figure 2 Graphical comparison of utilised cycles

Table 3 Chosen parameters of utilized cycles

\begin{tabular}{ccccc}
\hline cycle type & duration $(\mathrm{s})$ & distance $(\mathrm{m})$ & max speed $(\mathrm{km} / \mathrm{h})$ & aver. speed $(\mathrm{km} / \mathrm{h})$ \\
\hline IM240 & 240 & 3100 & 91.2 & 47.3 \\
NEDC & 1180 & 11023 & 120 & 33.3 \\
WLTC $^{1}$ & 1800 & 23266 & 131.1 & 46.5 \\
RDL $^{2}$ & 762 & 3315 & 50.0 & 15.7 \\
\hline
\end{tabular}

${ }^{1}$ WLTC - class 3b, ${ }^{2}$ Real Drive Lublin, [2]

to the selected vehicle. For this purpose, the field measurements of accelerating were carried out on a flat, levelled road of a good quality asphalt surface. The tested vehicle was accelerated to a speed of approx. 115 $\mathrm{km} / \mathrm{h}$. Then the powertrain system was disconnected and the vehicle run decelerating freely. During the coast down the speed of the vehicle was being recorded. However, relating to the vehicle, test track, test speed, atmospheric conditions and measuring equipment, several requirements were to be met for carrying out the coast down tests. The tests were performed several times following the procedures described in other publications [34-36]. Based on that, it was possible to assess the mechanical condition of the vehicle, chassis settings, influence of used tires and aerodynamic properties of the vehicle's body [34].

The determined run-off times between successive speeds decreasing from $110 \mathrm{~km} / \mathrm{h}$, every $10 \mathrm{~km} / \mathrm{h}$ were entered into the vehicle's data sheet in the software controlling the dynamometer. Thanks to that, the application could make the necessary calculations to determine the braking forces applied by the rollers to simulate the road movement resistances. After starting the procedure, the rollers propelled the vehicle wheels up to $110 \mathrm{~km} / \mathrm{h}$ and the coast down test was performed applying the calculated resistance forces. The coasting times were measured simultaneously. During the adjustment process, the dynamometer mapped the way of loading in subsequent tests as to obtain times in accordance with previously determined in the road conditions.

\subsubsection{Driving cycles}

Frequently used driving cycles were selected for the studies. These were IM240, NEDC and WLTC Class 3b and one own RDL test (Real Drive Lublin) developed based on urban driving in the city of Lublin. The tests lasted from 240 to 1800 seconds and, due to the unification of the procedures, were carried out on a warm engine.

The first one - IM240 test is a schedule recommended by the US EPA for emission testing of in-use light duty vehicles in inspection \& maintenance (I\&M) programs. The test was formulated based on selected segments of the FTP-75 test cycle. The IM240 is a short, 240 second test representing a $3.1 \mathrm{~km}$ route with a maximum speed of $91.2 \mathrm{~km} / \mathrm{h}$ and an average speed of $47.3 \mathrm{~km} / \mathrm{h}$ [2].

The next cycle was NEDC. It used to be a reference cycle for homologating vehicles until the introduction of Euro 6 standard in Europe. It is made of an urban part called ECE, which is repeated four times and an extraurban part, the EUDC [2]. That was the cycle used in the tested vehicle type approval procedure.

The WLTC cycles (including WLTC class $3 b$ ) are 


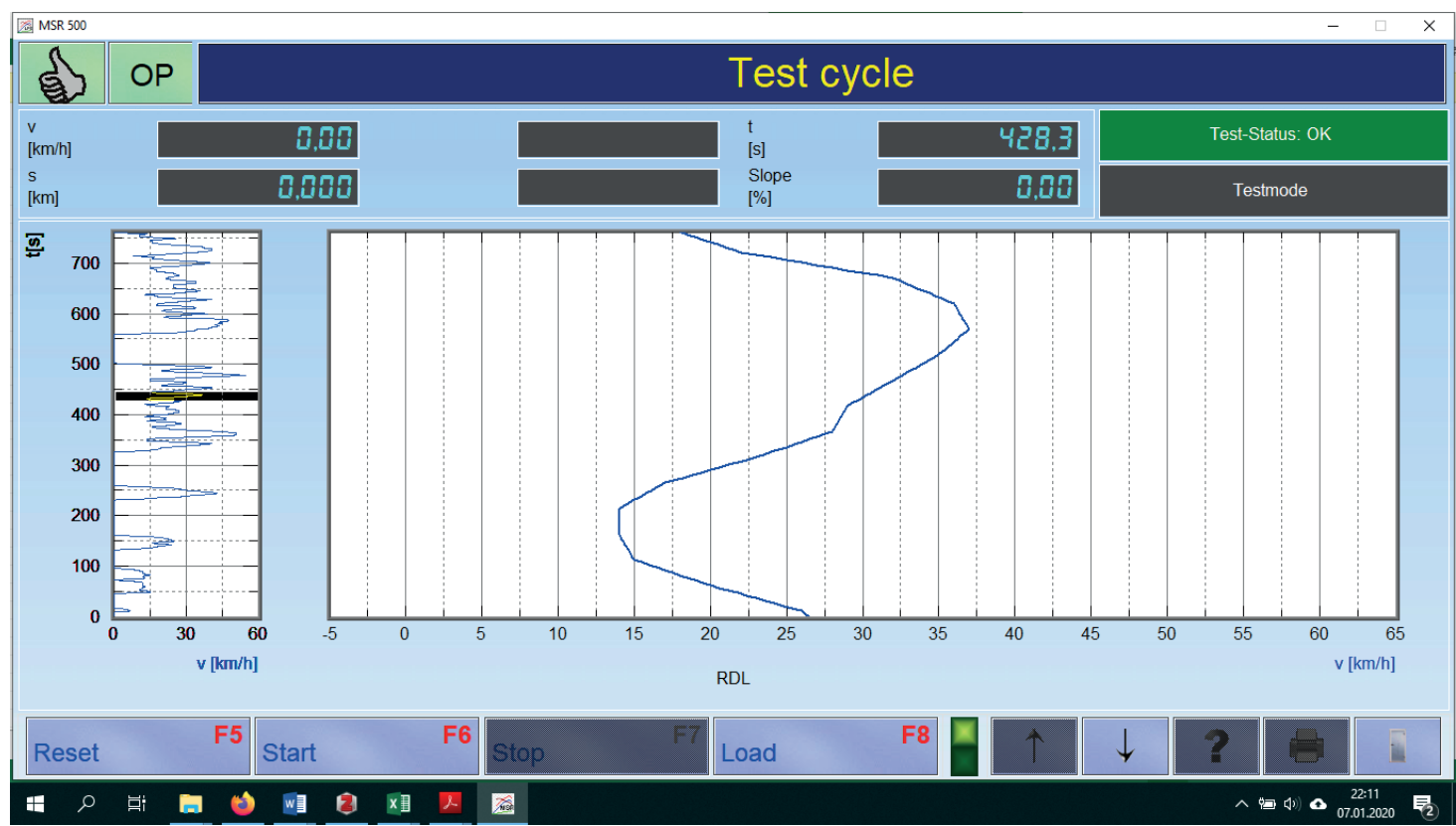

Figure 3 Example of the speed pattern of a driving cycle

part of the Worldwide harmonized Light vehicles Test Procedures (WLTP), published as UNECE Global technical regulation No 15 . The WLTP replaces the European NEDC based procedure for type approval testing of light-duty vehicles [2, 37].

The fourth cycle was developed by the authors of the manuscript as a part of other research and was used as it represented an example of a real driving speed pattern obtained in the center of Lublin. The length of RDL was 3312 meters. The drive duration was 762 seconds and the average speed was $15.7 \mathrm{~km} / \mathrm{h}$. The route was driven twice with use of the same vehicle (VW Golf A4). The speed was recorded by a smartphone GPS receiver and VAG (Volkswagen Audi Group) interface connected by the vehicle's OBD (OnBoard Diagnosis) link connector. Then, the data was worked over and introduced into the dynamometer software.

The speed patterns of the used cycles are presented in Figure 2 and their basic data parameters are collected in Table 3. All the cycles differ according to duration, distance, maximum and average speed or stops and they also present different ways of driving.

The conduction of the tests consisted in controlling the vehicle positioned at the dynamometer in such a way that it realized the speed displayed on the screen of the stand computer. Figure 3 presents an exemplary test screen, according to which the car was to drive.

The study covered measurements and recording of the following parameters:

- volumetric shares of chosen gas components - CO carbon oxide, $\mathrm{CO}_{2}$ carbon dioxide, $\mathrm{O}_{2}$ oxygen, $(\%)$ and $\mathrm{HC}$ unburned hydrocarbons, $\mathrm{NO}_{\mathrm{x}}$ nitrogen oxides, (ppm),

- $\lambda$ air excess coefficient computed by the analyser,

- emission of particulate matter - PM (Particle Matter), (mg. $\left.\mathrm{m}^{-3}\right)$,
- engine rotational speed - RPM, $\left(\mathrm{min}^{-1}\right)$

- $\quad$ engine oil temperature - T, $\left({ }^{\circ} \mathrm{C}\right)$,

- manifold air flow - MAF (g/s),

- fuel dose (injection quantity/injector) - IQ (g/cycle)

The measurement results were recorded at frequency of $1 \mathrm{~Hz}$. Next, the mass emission of the distinguished exhaust gas components was computed accordingly to the described earlier methodology.

\section{Research results and analysis}

As a result of measurements, the required parameters were recorded. Figure 4 presents an exemplary diagram (print screen) of the recorded values of volume shares of selected exhaust components, including solid particles, as a function of time for the last 250 seconds of the NEDC cycle.

\subsection{Fuel consumption comparison for different cycles}

The diagram (Figure 5) summarizes the fuel consumption in 4 different driving cycles with the manufacturer's data of the tested vehicle. Fuel consumption for each cycle was determined based on the emissions and simultaneously based on OBD (injection quantity) data. In three cases (NEDC, WLTC, RDL), when calculating the fuel consumption by the OBD data method, higher values were obtained than in the case of the first method. Only in the IM240 cycle the fuel consumption determined based on emissions turned out to be higher.

The measurement results for the NEDC cycle are similar to the manufacturer's data for the mixed driving 


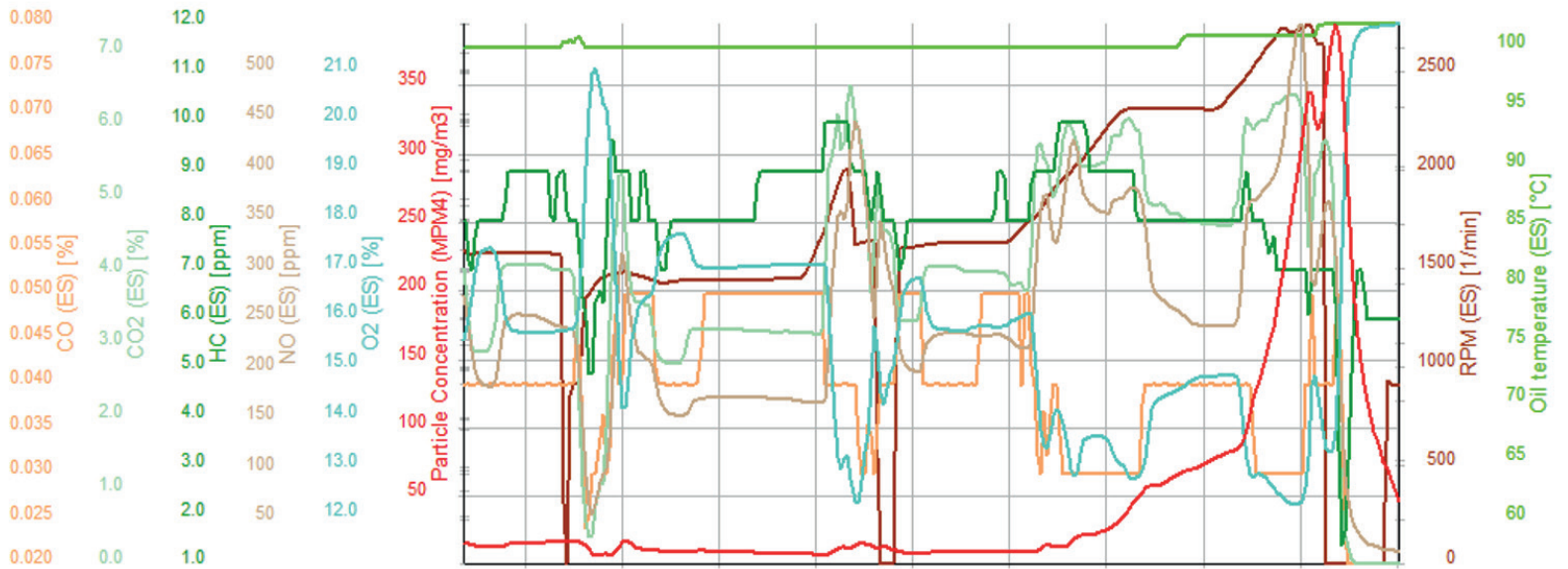

Figure 4 Recorded emissions shares tested accordingly to NEDC

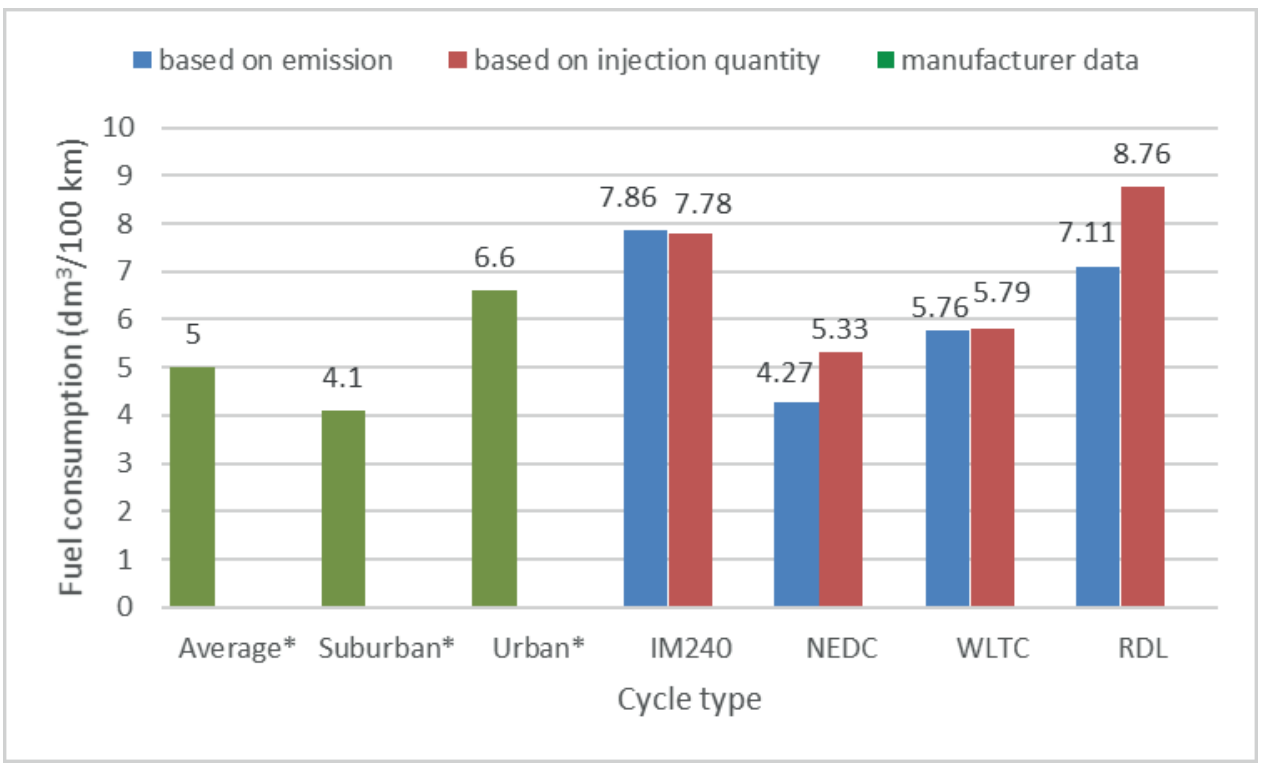

Figure 5 Fuel consumption comparison for chosen cycles (*EU 99/100)

patterns, while the results obtained for the WLTC (5.76 $\mathrm{dm}^{3}$ and $5.79 \mathrm{dm}^{3}$ ) exceed the manufacturer's data. The average consumption for the WLTC cycle, which replaced the European NEDC test, is approx. $16 \%$ higher than it would appear from the vehicle manufacturer's data and approx. $18 \%$ and $9 \%$ higher than the values obtained in the NEDC tests for fuel consumption determined according to emissions and $\mathrm{OBD}$, respectively. The higher fuel consumption in the WLTC cycle can be confirmed by various comparisons and the differences depending on the vehicle can reach values of up to 1.0 or $2.0 \mathrm{dm}^{3}$ per $100 \mathrm{~km}$ [38].

The authors' RDL driving test indicates even higher fuel consumption, but it is a cycle based solely on urban driving and therefore can be referred to the values indicated by the vehicle manufacturer for driving in such conditions $\left(6.6 \mathrm{dm}^{3}\right)$. Even in this comparison, the measurement result were $8 \%$ and $32 \%$ higher for emissions and OBD calculations, respectively. Similarly, the high consumption was observed for the IM240 cycle. Similar tendencies are observed in the real driving tests performed by other investigators [39-40].

\subsection{Carbon dioxide emission}

The tested vehicle was to emit $132 \mathrm{~g} / \mathrm{km}$ of $\mathrm{CO}_{2}$ during the type-approval test. This value was compared to emissions measured in four driving cycles. The results are presented in Figure 6. Of all the tests, $\mathrm{CO}_{2}$ emissions closest to the values from the type-approval tests were found for the NEDC cycle measurement (Figure 6). For the WLTC cycle emissions were almost $22 \%$ higher than manufacturer's data ( $161 \mathrm{~g} / \mathrm{km}$ in WLTC and $132 \mathrm{~g} / \mathrm{km}$ by manufacturer). This result is confirmed by various tests and observations of independent centres [38, 41-42]. As might be expected, the $\mathrm{CO}_{2}$ test results showed trends consistent with those obtained for the fuel consumption (Figure 5). In the case of the authors' RDL driving test, the emission was almost $40 \mathrm{~g} / \mathrm{km}$ higher than according to the manufacturer's data.

That can find confirmation in numerous publications, the authors of which indicate the influence of the driving cycle speed profile for the energy demand of a vehicle and the resulting fuel consumption and $\mathrm{CO}_{2}$ emissions [43-44]. Parameters, such as the average and maximum 


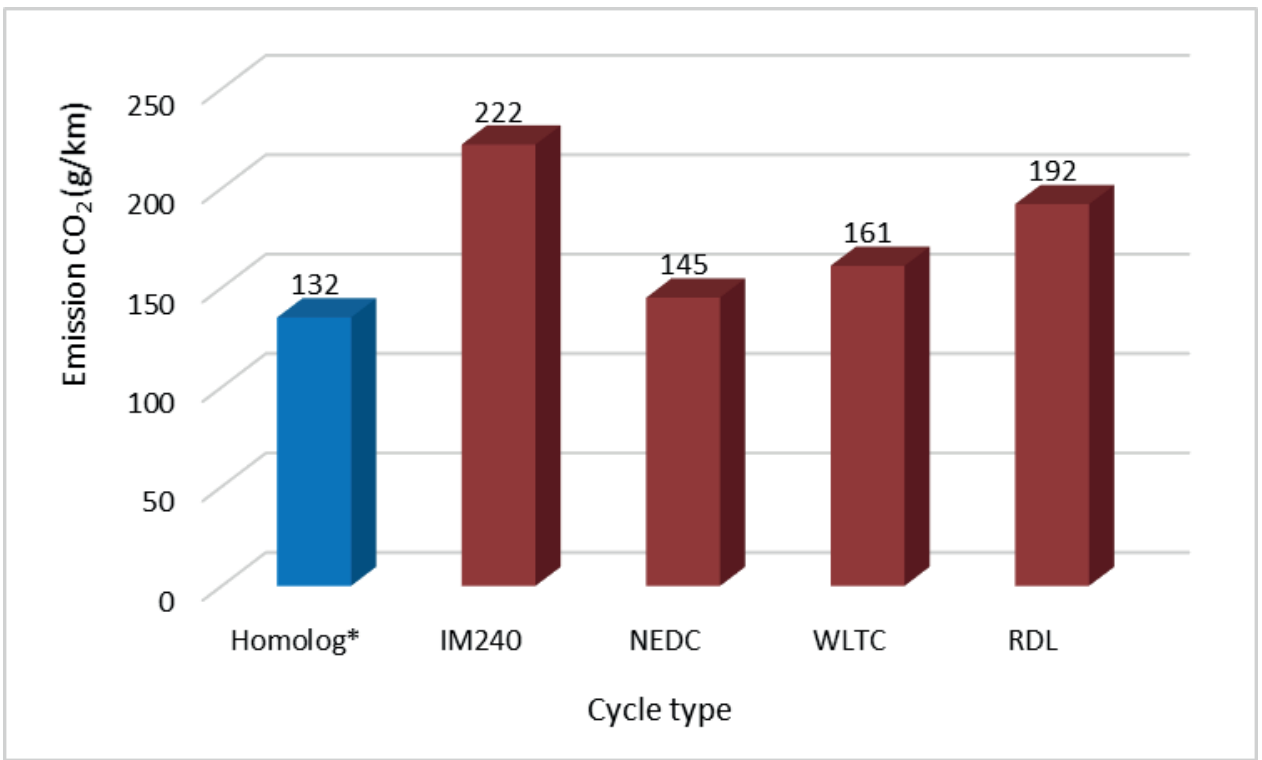

Figure 6 Carbon dioxide emission comparison for chosen cycles

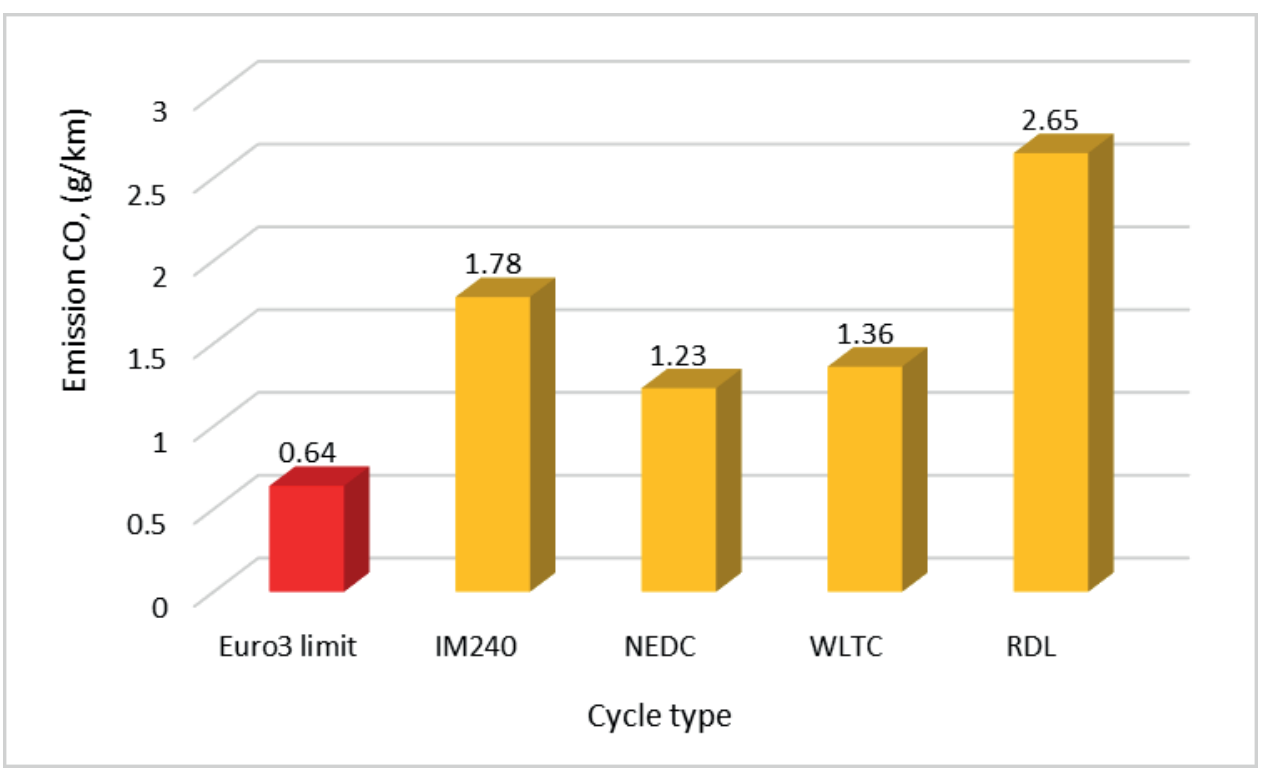

Figure 7 Carbon monoxide emission comparison for chosen cycles

speeds, the share and values of acceleration and deceleration in the speed profile, determine the energy demand of a vehicle necessary to drive the driving cycle. Thus, the cycle itself may cause changes in the energy and fuel consumption of the tested vehicle [45-47].

\subsection{Carbon monoxide emission}

According to the Euro 3 standard, a vehicle of this type can emit up to $0.64 \mathrm{~g} / \mathrm{km}$ of carbon monoxide. However, for tests carried out on a given vehicle with a mileage of approximately $312000 \mathrm{~km}$, the results were much higher (Figure 7).

The lowest value was obtained for the NEDC cycle $(1.23 \mathrm{~g} / \mathrm{km})$, while the highest was the emission determined for the urban RDL cycle $(2.65 \mathrm{~g} / \mathrm{km})$. This means that the measured values are 2 to 4 times higher than the normative data. Jaworski et al. in example of other vehicle presents problems in repeatability of the exhaust pollutant emission results [48]. However, the differences are not so significant as observed in presented in this case. Such situation may be caused rather by operational wear of the oxidation reactor, but may also be a result of malfunctions of fuel injectors or air inlet problems [49-50]. Analysing trends related to the $\mathrm{CO}$ emissions in individual tests, it can be concluded that the measured values show similarities to the results of the $\mathrm{CO}_{2}$ emissions and fuel consumption measured based on the emissions.

\subsection{Nitrogen oxides emission}

According to the Euro 3 standard, the tested vehicle type could emit nitrogen oxides up to the level 


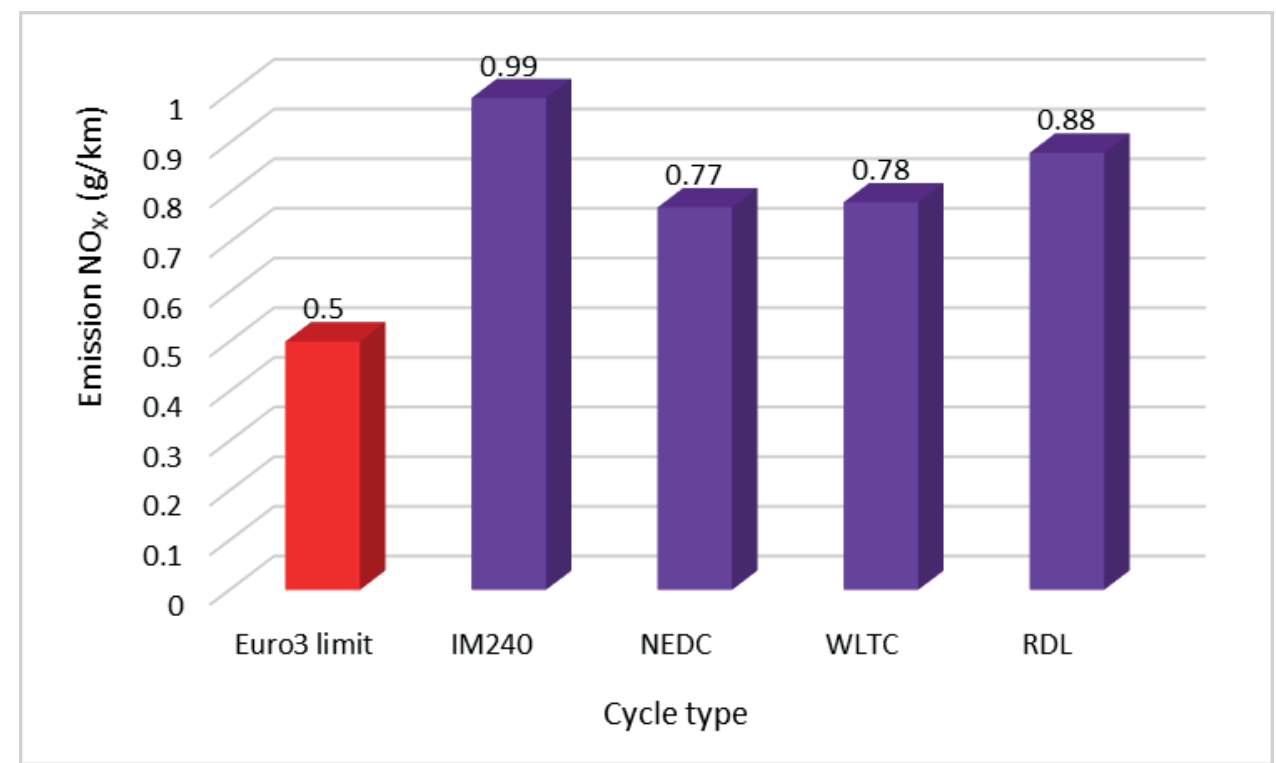

Figure 8 Nitrogen oxides emission comparison for chosen cycles

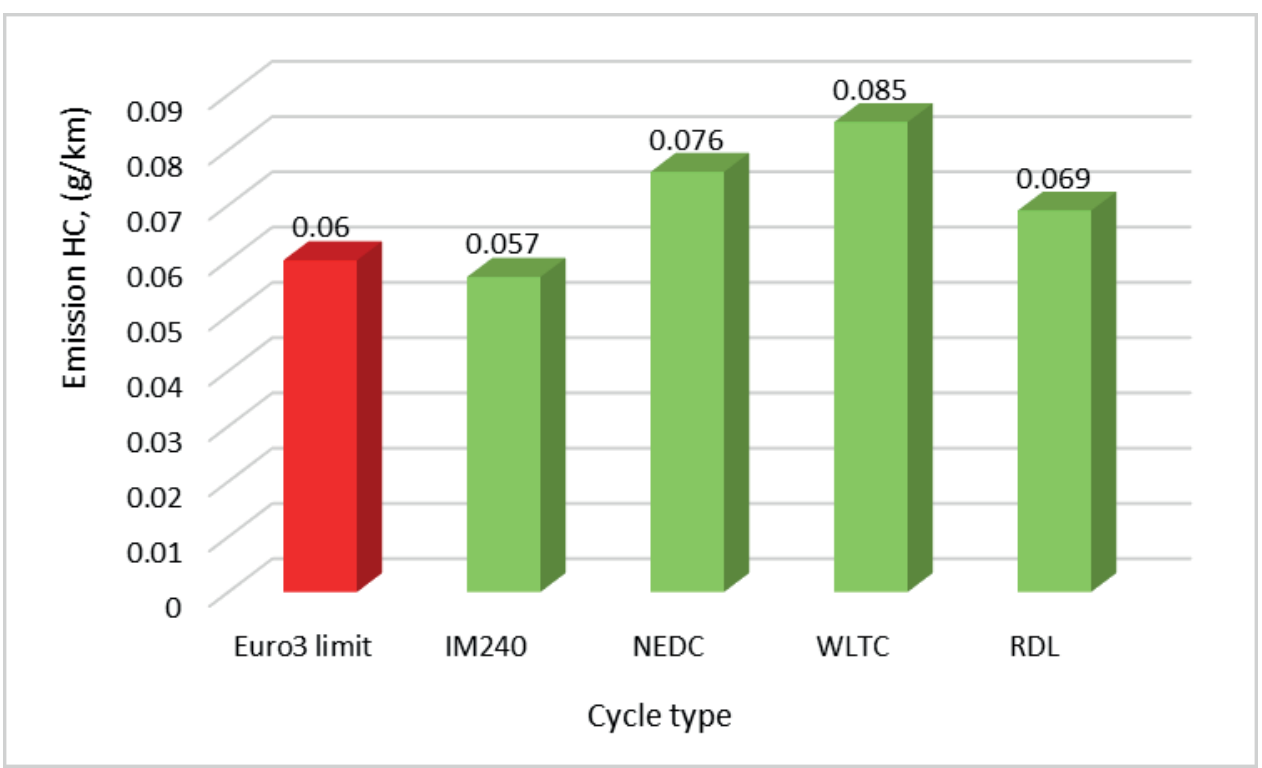

Figure 9 Hydrocarbons emission comparison for chosen cycles

of $0.5 \mathrm{~g} / \mathrm{km}$. All the results from the applied driving cycles were definitely higher than the permissible values. The emission of these components during the European NEDC test was 54\% higher than the permissible limit according to Euro $3(0.50 \mathrm{~g} / \mathrm{km}$ - Euro 3 and $0.77 \mathrm{~g} / \mathrm{km}$ - measurement according to NEDC). It can be assumed that these differences, like in the case of $\mathrm{CO}$ emissions, were caused by the wear of the catalytic converter or blocked EGR valve. Research of Huang at al. and other researchers confirms these assumptions [50-52]. Comparing emissions in the NEDC and WLTC cycles, a small difference $(0.01 \mathrm{~g} / \mathrm{km}$ more for WLTC) can be seen between them. Emission values of nitrogen oxides are shown in Figure 8, however, they are not as high in relation to the Euro 3 standard as the CO emissions.

\subsection{Hydrocarbon emissions}

Hydrocarbons are formed mainly as a result of incomplete combustion of fuel. They react quickly with oxygen and nitrogen compounds, which creates, among others peroxides and aldehydes.

According to the Euro 3 standard for diesel vehicles, the hydrocarbon emission should not exceed $0.06 \mathrm{~g} /$ $\mathrm{km}$. In the case of the performed tests, such emission ranged from $0.045 \mathrm{~g} / \mathrm{km}$ (RDL) to $0.085 \mathrm{~g} / \mathrm{km}$ (WLTC and RDL) (Figure 9). Emissions from the NEDC test were $23 \%$ higher than emissions from the standard (0.06 g/ km Euro 3 and $0.076 \mathrm{~g} / \mathrm{km} \mathrm{NEDC),} \mathrm{which} \mathrm{may}$ also suggest malfunctions of injectors or combustion problems combined with exhaust gas recirculation system [50]. Comparing the European NEDC test with 


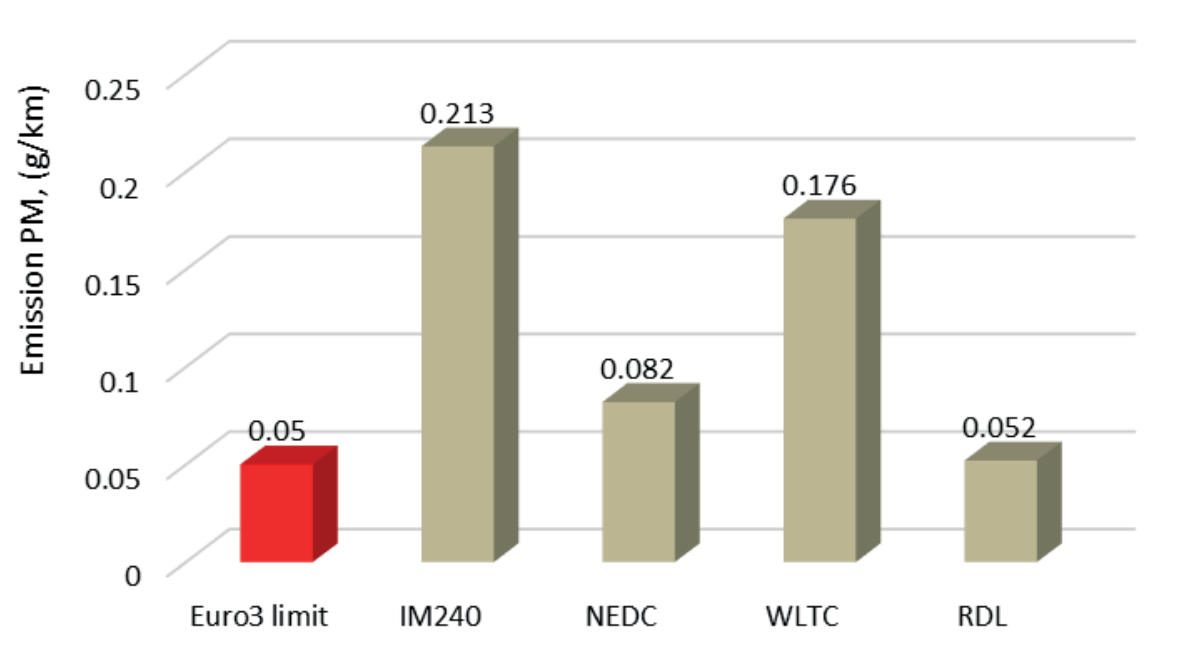

Figure 10 Particle matter emission comparison for chosen cycles

the new world WLTC test, it can be seen that emissions from the latter test were about $16 \%$ higher. On the other hand, relatively low emission for the RDL cycle $(0.045 \mathrm{~g} /$ $\mathrm{km}$ ) was unexpected.

\subsection{Particle matter emission}

The PM (particle matter) are all the substances that leave the exhaust system in solid or liquid state. The high particulate emissions occur when the engine is started and its temperature is low. Increased PM emissions also occur with local oxygen deficiency, which can take place during a sharp increase of engine load and increase of fuel dose. Increased PM emissions may result from many irregularities. That can be caused by a malfunction of the oxidation catalytic converter, leaking injectors or problems with the intake and exhaust gas recirculation systems [49-50, 53].

Figure 10 shows the particulate emissions measured during the cycles. The particulate emission limit for the Euro 3 standard is $0.05 \mathrm{~g} / \mathrm{km}$. The results of all the tests exceeded the Euro 3 limit. However, there were two cycles that generated much higher values. These were IM240 and WLTC. In those cases, emissions exceeded the permissible limit of Euro 3 almost four times. The limit value was exceeded by $326 \%$ and by $252 \%$ for IM240 and WLTC, respectively. In the case of the NEDC test, emissions were "only" $64 \%$ higher. In contrast, urban RDL generated the lowest amount of particles with a value of $0.052 \mathrm{~g} / \mathrm{km}$.

\section{Conclusions}

Based on the conducted research and evaluation of obtained results, the following conclusions can be drawn:

Fuel consumption and exhaust emissions show strong differentiation in relation to the driving cycles used in the tests.
The fuel consumption determined based on the exhaust gas emitted was, in three out of four cycles, at a lower level than calculated based on the injection injected quantity shown by the engine control unit. The highest values were found for the urban driving (RDL) at low speed and the lowest for the NEDC cycle.

The measurement results of exhaust emissions and fuel consumption for the WLTC harmonized driving test were significantly higher than for the NEDC test. This was probably due to greater speed variability in the WLTC cycle, which brings this cycle closer to the real driving conditions.

The results of emission of selected exhaust components in the analysed driving cycles in each case exceeded the values allowed by the Euro 3 standard (based on the NEDC cycle). In addition, it should be emphasized that the tests were carried out based on a vehicle that had been in operation for over 18 years, with a mileage exceeding $300000 \mathrm{~km}$, which could be associated with the deficiencies of the exhaust aftertreatment system.

Summing up, it should be emphasized that the exhaust emissions and fuel consumption, on the example of the tested vehicle, definitely exceed the norms. Only in the case of the NEDC cycle and two parameters, i.e. fuel consumption and carbon dioxide emissions, the values obtained were similar to those of the Euro 3 standard. However, it should be noted that the NEDC cycle was the basis for the approval tests of this vehicle. The emission of other components definitely exceeds the values specified in that standard. The reason for this may be age and thus the wear and tear of the vehicles' components.

It should be emphasized that these results apply only to this particular vehicle in a given technical condition and cannot be declared as general conclusions. However, the average car age in Poland is over fourteen years. That means that there is a serious probability of finding other vehicles in a similar technical condition that exceed the emission limits. 


\section{References}

[1] TUCKI, K., MRUK, R., ORYNYCZ, O., BOTWINSKA, K., GOLA, A., BACZYK, A. Toxicity of exhaust fumes (CO, NOx) of the compression-ignition (diesel) engine with the use of simulation. Sustainability [online]. 2019, 11, 2188. eISSN 2071-1050. Available from: https://doi.org/10.3390/su11082188

[2] Engine emission standards [online] [accessed 2020-01-19]. Available from: https://dieselnet.com/standards/\#eu

[3] SUAREZ-BERTOA, R., VAlVERDE, V., ClAIROTTE, M., PAVlOVIC, J., GIECHASKIEL, B., FRANCO, V., KREGAR, Z., ASTORGA, C. On-road emissions of passenger cars beyond the boundary conditions of the realdriving emissions test. Environmental Research [online]. 2019, 176, 108572. ISSN 0013-9351. Available from: https://doi.org/10.1016/j.envres.2019.108572

[4] KURANC, A., WASILEWSKI, J.: Proecological trends in development of piston combustion engines. Diesel engines - new challenges 2010 (in Polish). Radom: Instytut Naukowo-Wydawniczy SPATIUM, 2010. p. 91-112. ISBN 978-83-928882-7-7

[5] SZPICA, D., CZABAN, J. The problems of investigations of vehicles equipped with diesel engines with FAP filter of solid particles in context of the EURO 5 standard / Problematyka badan pojazdow wyposazonych w silniki wysokoprezne z filtrami czastek stalych w kontekscie obowiazywania normy EURO 5 (in Polish). Archiwum Motoryzacji. 2009, 4, p. 261-271. ISSN 1234-754X, eISSN 2084-476X.

[6] SKRUCANY, T., SEMANOVA, S., FIGLUS, T., SARKAN, B., GNAP, J. Energy intensity and GHG production of chosen propulsions used in road transport. Communications-Scientific Letters of the University of Zilina [online]. 2017, 19(2), p. 3-9. ISSN 1335-4205, eISSN 2585-7878. Available from: http://komunikacie.uniza.sk/index.php/ communications/article/view/174

[7] REGULATION (EU) 2019/631 OF THE EUROPEAN PARLIAMENT AND OF THE COUNCIL of 17 April 2019 - setting $\mathrm{CO}_{2}$ emission performance standards for new passenger cars and for new light commercial vehicles and repealing Regulations (EC) No 443/2009 and (EU) No 510/2011.

[8] Exhaust emissions legislation in Europe [online] [accessed 2020-06-01]. Available from: http://vda.de

[9] SHAHED, S., BAUER, K. H. Parametric studies of the impact of turbocharging on gasoline engine downsizing. SAE International Journal of Engines [online]. 2009, 2, p. 1347-1358. ISSN 1946-393, eISSN 1946-3944. Available from: https://doi.org/10.4271/2009-01-1472

[10] TURNER, J., POPPLEWELL, A., PATEL, R., JOHNSON, T., DARNTON, N., RICHARDSON, S., BREDDA, S., TUDOR, R., BITHELL, C., JACKSON, R. Ultra boost for economy: extending the limits of extreme engine downsizing. SAE International Journal of Engines [online]. 2014, 7, p. 387-417. ISSN 1946-393, eISSN 19463944. Available from: https://doi.org/10.4271/2014-01-1185

[11] GARDYNSKI, L., KALDONEK, J. Research on lubrication properties of selected raw plant and animal materials. Transport [online]. 2020, 35, p. 20-25. ISSN 1648-4142, eISSN 1648-3480. Available from: https://doi. org/10.3846/transport.2020.11961

[12] MAKAREVICIENE, V., MATIJOSIUS, J., PUKALSKAS, S., VEGNERIS, R., KAZANCEVA, I., KAZANCEV, K. The exploitation and environmental characteristics of diesel fuel containing rapeseed butyl esters. Transport [online]. 2013, 28, p. 158-165. ISSN 1648-4142, eISSN 1648-3480. Available from: https://doi.org/10.3846/164841 42.2013.801364

[13] ZDZIENNICKA, A., SZYMCZYK, K., JANCZUK, B., LONGWIC, R., SANDER, P. Surface, volumetric and wetting properties of oleic, linoleic and linolenic acids with regards to application of canola oil in diesel engines. Applied Sciences [online]. 2019, 9(17), 3445. eISSN 2076-3417. Available from: https://doi.org/10.3390/app9173445

[14] LEBEDEVAS, S., PUKALSKAS, S., DAUKSYS, V., RIMKUS, A., MELAIKA, M., JONIKA, L. Research on fuel efficiency and emissions of converted diesel engine with conventional fuel injection system for operation on natural gas. Energies [online]. 2019, 12, 2413. eISSN 1996-1073. Available from: https://doi.org/10.3390/ en12122413

[15] LEBEDEVAS, S., PUKALSKAS, S., ZAGLINSKIS, J., MATIJOSIUS, J. Comparative investigations into energetic and ecological parameters of camelina-based biofuel used in the $1 \mathrm{Z}$ diesel engine. Transport [online]. 2012, 27, p. 171-177. ISSN 1648-4142, eISSN 1648-3480. Available from: https://doi.org/10.3846/16484142.2012.6 94078

[16] MIKULSKI, M., BALAKRISHNAN, P. R., HUNICZ, J. Natural gas-diesel reactivity controlled compression ignition with negative valve overlap and in-cylinder fuel reforming. Applied Energy [online]. 2019, 254, 113638. ISSN 0306-2619. Available from:10.1016/j.apenergy.2019.113638

[17] Electric car sales results in Europe (Q1 2019) / Wyniki sprzedazy samochodow elektrycznych w Europie (I kwartal 2019) - Electric cars / Samochody elektryczne (in Polish) [online] [accessed 2020-06-01]. Available from: https://elektrowoz.pl/auta/wyniki-sprzedazy-samochodow-elektrycznych-w-europie-i-kwartal-2019 
[18] LUBCZANSKI, M. Electric cars with a new record / Samochody elektryczne z nowym rekordem (in Polish) [online] [accessed 2020-05-02]. Available from: https://e.autokult.pl/34559,sprzedaz-samochodow-elektrycznychw-i-polroczu-2019-roku-auta-nowe-uzywane

[19] How much does driving an electric car really cost? „The trip has stopped paying off on the highways“ / Ile naprawde kosztuje jazda autem elektrycznym? "Podroz przestala sie oplacac na autostradach" (in Polish) [online] [accessed 2020-012-01]. Available from: http://forsal.pl/artykuly/1448077,samochod-elektryczny-zuzycie-energiiw-trasie-koszty-ladowania.html

[20] BERMAN, B. Mazda wrongly says long-range EVs are worse for $\mathrm{CO}_{2}$ than diesel cars - Electrek [online] [accessed 2020-12-01]. Available from: https://electrek.co/2019/12/29/mazda-says-long-range-evs-are-worse-forco2-than-diesel-cars

[21] SLIWA, M. Sale of electric cars in the world. Poland is far behind / Sprzedaz aut elektrycznych na swiecie. Polska daleko w tyle (in Polish) [online] [accessed 2020-06-01]. Available from: https://moto.rp.pl/tu-i-teraz/29120sprzedaz-aut-elektrycznych-na-swiecie-polska-daleko-w-tyle

[22] The average age of cars in Poland and Europe / Sredni wiek samochodow w Polsce i w Europie (in Polish) [online] [accessed 2020-06-01]. Available from: https://vn24bis.pl/article/url/978789

[23] KURANC, A. Emission of the fume's harmful components in the control tests upon the chosen population of vehicles / Emisja szkodliwych skladnikow spalin w badaniach kontrolnych wybranej populacji pojazdow samochodowych (in Polish). Autobusy: technika, eksploatacja, systemy transportowe. 2011, 12(10), p. 282-290. ISSN 1509-5878, eISSN 2450-7725.

[24] LARISH, J. Population structure of cars and the results of periodical supervising for exhaust emissions carried out on the vehicle inspection station / Struktura populacji samochodow i wyniki badan emisji spalin wykonanych na stacji kontroli pojazdow ASO (in Polish). Silniki Spalinowe [online]. 2011, 50(3). ISSN 0138-0346.

[25] SZPICA, D.: Coefficient of engine flexibility as a basis for the assessment of vehicle tractive performance. Chinese Journal of Mechanical Engineering [online]. 2019, 32, 39. ISSN 1000-9345, eISSN 2192-8258. Available from: https://doi.org/10.1186/s10033-019-0352-8

[26] MAHA. Motor gas tester MGT 5 five-gas tester. Technical handbook. MAHA Maschinenbau Haldenwang GmbH \& Co. 1999.

[27] MAHA. MPM4 - Particle Measurement Unit. Original Operating Instructions. MAHA Maschinenbau Haldenwang GmbH \& Co. 2008.

[28] PIEKARSKI, W., KURANC, A. Exhaust emissions and fuel consumption in a chassis dynamometer load test in the aspect of modification of an engine controlling system. Combustion Engines [online]. 2017, 171(4), p. 11-16. ISSN 2300-9896, eISSN 2658-1442. Available from: https://doi.org/10.19206/CE-2017-402

[29] ROCHA-HOYOS, J. C., ZAMBRANO, D., PORTIllA, A., ERAZO, G., TORRES, G., LlANES-CEDENO, E. Analysis of gases of the engine of a vehicle through static and dynamic tests / Analisis de gases del motor de un vehiculo a traves de pruebas estaticas y dinamicas (in Spaniah). Ciencia Unemi [online]. 2018, 11(28), p. 97-108. ISSN 1390-4272, eISSN 1390-4272. Available from: http://ojs.unemi.edu.ec/index.php/cienciaunemi/article/ view/711

[30] KURANC, A. Exhaust emission test performance with the use of the signal from air flow meter. Eksploatacja i Niezawodnosc - Maintenance and Reliability [online]. 2015, 17(1), p. 129-134. ISSN 1507-2711. Available from: https://doi.org/10.17531/ein.2015.1.17

[31] Electronics for the automotive industry - Viaken / Elektronika dla motoryzacji - Viaken (in Polish) [online] [accessed 2020-05-02]. Available from: https://viaken.pl/pl/vag-usb-kkl-line-2-linie-k-we-wtyku-obd2.html

[32] Regulation No 83 of the Economic Commission for Europe of the United Nations (UN/ECE) - Uniform provisions concerning the approval of vehicles with regard to the emission of pollutants according to engine fuel requirements. Official Journal of the European Union. L 42/1. 2012.

[33] MAHA. MSR - Single Roller Dynamometer. Original operating instructions. 2011.

[34] KNEZ, M., JEREB, B., OBRECHT, M. Factors influencing the purchasing decisions of low emission cars: a study of Slovenia. Transportation Research Part D: Transport and Environment [online]. 2014, 30, p. 53-61. ISSN 1361-9209. Available from: https://doi.org/10.1016/j.trd.2014.05.007

[35] SARKAN, B., SKRUCANY, T., SEMANOVA, S., MADLENAK, R., KURANC, A., SEJKOROVA, M., CABAN, J. Vehicle coast-down method as a tool for calculating total resistance for the purposes of type-approval fuel consumption. Scientific Journal of Silesian University of Technology. Series Transport [online]. 2018, 98, p. 161-172. ISSN 0209-3324, eISSN 2450-1549. Available from: https://doi.org/10.20858/sjsutst.2018.98.15

[36] SARKAN, B., STOPKA, O., CHOVANCOVA, M., KURANC, A. Simulating real driving conditions on the single roller dynamometer: a case study in terms of the fuel consumption measurement. In: 11th International Science - Technical Conference Automotive Safety: proceedings [online]. 2018. p. 1-6. Available from: https://doi.org/10.1109/AUTOSAFE.2018.8373313 
[37] Worldwide harmonized light vehicles test procedure. German association of the automotive industry (VDA) WLTP [online] [accessed 2020-06-02]. Available from: http://vda.de

[38] KARCZMARZ, G. In WLTP cars consume about 1 liter/100 km more than the NEDC / W WLTP samochody zuzywaja okolo 1 litr/100 km wiecej niz wynikalo to z NEDC (in Polish) [online] [accessed 2020-01-20]. Available from: https://spidersweb.pl/autoblog/porownanie-wltp-vs-nedc

[39] JAWORSKI, A., KUSZEWSKI, H., LEJDA, K., USTRZYCKI, A., MADZIEL, M., LATALA, D. New procedure of examination of exhaust emission test from motor vehicles wit the use of road test / Nowa procedura przeprowadzania badan emisji spalin $\mathrm{z}$ pojazdow samochodowych $\mathrm{z}$ wykorzystaniem testow drogowych (in Polish). In: Scientific - Practical Conference Bus Construction and Passenger Transportation in Ukraine: proceedings. 2018. ISBN 966-941-140-8, p. 119-125.

[40] MERKISZ, J., PIELECHA, J., NOWAK, M. Exhaust emissions from vehicles in real traffic conditions on the example of Poznan agglomeration / Emisja zanieczyszczen z pojazdow w rzeczywistych warunkach ruchu na przykladzie aglomeracji poznanskiej (in Polish). Postepy Nauki i Techniki [online]. 2012, 15, p. 103-115. ISSN 2080-4075.

[41] NEDC tested vs NEDC correlated - JATO [online] [accessed 2020-01-27]. Available from: https://www.jato.com/ wp-content/uploads/2018/08/CO2-chart.jpeg

[42] Current legal framework: NEDC (New European Driving Cycle) [online] [accessed 2020-06-02]. Available from: http://vda.de

[43] FICE, M., SETLAK, R. Energy analysis of the real driving cycles / Analiza energetyczna rzeczywistych cykli jazdy (in Polish). Zeszyty Problemowe - Maszyny Elektryczne [online]. 2011, 2(90), p. 99-103. ISSN 0239-3646, eISSN 2084-5618.

[44] PIELECHA, I., PIELECHA, J. Simulation analysis of electric vehicles energy consumption in driving tests. Eksploatacja i Niezawodnosc - Maintenance and Reliability [online]. 2019, 22(1), p. 130-137. ISSN 1507-2711. Available from: https://doi.org/10.17531/ein.2020.1.15.

[45] KROPIWNICKI, J. Assessment of energy efficiency of motor vehicles with internal combustion engines / Ocena efektywnosci energetycznej pojazdow samochodowych z silnikami spalinowymi (in Polish). Gdansk: Wydawnictwo Politechniki Gdanskiej, 2011. ISBN 978-83-7348-357-6.

[46] MOCK, P., KUHLWEIN, J., TIETGE, U., FRANCO, V., BANDIVADEKAR, A., GERMAN, J. The WLTP: How a new test procedure for cars will affect fuel consumption values in the EU. In: International Council on Clean Transportation ICCT 2014: proceedings. 2014.

[47] UBYSZ, A. Energy conservation in motor vehicles / Poszanowanie energii w pojazdach samochodowych (in Polish). Gliwice: Wydawnictwo Politechniki Slaskiej, 2011.

[48] JAWORSKI, A., KUSZEWSKI, H., USTRZYCKI, A., BALAWENDER, K., LEJDA, K., WOS, P. Analysis of the repeatability of the exhaust pollutants emission research results for cold and hot starts under controlled driving cycle conditions. Environmental Science and Pollution Research International [online]. 2018, 25(18), p. 17862-17877. ISSN 0944-1344, eISSN 1614-7499. Available from: https://doi.org/10.1007/s11356-018-1983-5

[49] RESITOGLU, I. A., ALTINISIK, K., KESKIN, A. The pollutant emissions from diesel-engine vehicles and exhaust aftertreatment systems. Clean Technologies and Environmental Policy [online]. 2015, 17(1), p. 15-27. ISSN 1618-954X, eISSN 1618-9558. Available from: https://doi.org/10.1007/s10098-014-0793-9

[50] HUANG, Y., NG, E. C. Y., YAM, Y.-S., LEE, C. K. C., SURAWSKI, N. C., MOK, W.-C., ORGAN, B., ZHOU, J. L., CHAN, E. F. C. Impact of potential engine malfunctions on fuel consumption and gaseous emissions of a Euro VI diesel truck. Energy Conversion and Management [online]. 2019, 184, p. 521-529. ISSN 0196-8904. Available from: https://doi.org/10.1016/j.enconman.2019.01.076

[51] TOMPKINS, B. T. SONG, H., JACOBS, T. J. Particulate matter emissions from late injection high EGR low temperature diesel combustion. In: Internal Combustion Engine Division Fall Technical Conference: proceedings [online]. 2011. ICEF2011-60067. ISBN 978-0-7918-4442-7, p. 373-381. Available from: https://doi.org/10.1115/ ICEF2011-60067

[52] STEFANOPOULOU, A. G., KOLMANOVSKY, I. FREUDENBERG, J. S. Control of variable geometry turbocharged diesel engines for reduced emissions'. IEEE Transactions on Control Systems Technology [online]. 2000, 8(4), p. 733-745. ISSN 1063-6536, eISSN 1558-0865. Available from: https://doi.org/10.1109/87.852917

[53] HUANG, C., LOU, D., HU, Z., FENG, Q., CHEN, Y., CHEN, C., TAN, P., YAO, D. A PEMS study of the emissions of gaseous pollutants and ultrafine particles from gasoline-and diesel-fueled vehicles. Atmospheric Environment [online]. 2013, 77, p. 703-710. ISSN 1352-2310. Available from: https://doi.org/10.1016/j.atmosenv.2013.05.059 